\title{
Does Interest Rate Influence Demand for Money? An Empirical Evidence from Ghana
}

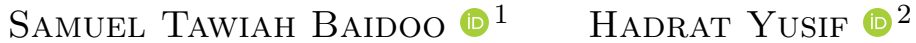

Received: 13.02.2019; Revised: 06.04.2019; Accepted: 30.04.2019

\begin{abstract}
This paper investigates whether interest rate influence demand for money in Ghana using annual time series from 1980 to 2016. Demand for money is measured by broad monetary aggregate $(\mathrm{M} 2+)$ whilst the rate of interest is proxied by the 91-day Treasury bill rate. Other variables included in the study are real income, inflation and exchange rate. The bounds testing approach to cointegration within the autoregressive distributed lag (ARDL) framework is employed as the estimation technique. The results show that interest rate has no significant influence on demand for money in Ghana in both the long and short run. It is also found that real income has positive and significant effect on demand for money in the long run. In the short run, inflation exerts negative and significant influence on money demand. Based on the insignificant relationship between interest rate and money demand, it is recommended that monetary authorities should not focus much on interest rate when designing monetary policies that are geared towards stabilizing the economy to expedite economic growth. However, authorities should focus more on inflation and real income as these variables exert significant effect on demand for money.
\end{abstract}

JEL codes: E41, E43, E52, C22

Keywords: Demand for money; interest rate; monetary policy; ARDL; Ghana

\section{Introduction}

The Bank of Ghana was established in 1957 to replace the West African Currency Board and from that time both fiscal and monetary policies (exchange rate targeting and selective credit control) were employed to manage the Ghanaian economy. Unfortunately, macroeconomic instability continued to characterize the country, especially in

1 Corresponding Author: Department of Economics, Kwame Nkrumah University of Science and Technology, Kumasi, Ghana. (e-mail: samueltawiahbaidoo@yahoo.com).

2 Department of Economics, Kwame Nkrumah University of Science and Technology, Kumasi, Ghana. the 1970s and early 1980s. The government adopted International Monetary Fund's (IMF)/World Bank's structural adjustment programme (SAP) and financial liberalization programmes in the 1983. With financial liberalization, the use of monetary policy for economic management deepened.

In 1982, monetary authorities shifted from exchange rate targeting to monetary targeting as a means of addressing the macroeconomic instability. Again in 1992, open market operation (OMO) was adopted by the Bank of Ghana (BoG) to deliver stable low inflation (Kwakye, 2012). With the adoption of OMO, inflation uncertainty still remained a contentious subject as 
average annual inflation rate fluctuated between 59.46 percent and 10.92 percent from 1993 to 2006 (Mohammed et al., 2016). Ghana, thus followed countries like New Zealand, Canada, United Kingdom, Germany and South Africa, and adopted full-fledged inflation targeting in 2007 (flexible inflation targeting was adopted in 2002). Inflation targeting as monetary instrument was aimed at maintaining stable low inflation. Kumo (2015) reports that inflation targeting was expected to maintain the inflation rate within the target range and reduce its volatility.

The Monetary Policy Committee of the Bank of Ghana was empowered to come out with the monetary policy rate (MPR) on quarterly basis. In November 2016, for example, the MPR was 25.5 percent and by July, 2017, it had been reduced to 21 percent, a total reduction of 450 bps (Bank of Ghana, 2017) . The reduction in MPR is aimed at reducing interest rate charged by commercial banks and thereby reducing the cost of borrowing by investors which could influence the consumer price index (CPI) and hence inflation rate. The ultimate goal of this instrument has been to achieve sustainable high economic growth and create jobs for the citizens (see for instance Puni et al., 2014; Mohammed et al., 2016).

However, Goldfeld and Sichel (1990), Goldfeld (1989), Osei (2016) have argued that demand for money and a stable demand for money function are critical for the use of monetary policy. Valadkhani (2008) reports that the demand for money and its main determinants (real income, inflation, interest rate and exchange rate) are essential components in the conduct of monetary policy, especially in the era of inflation targeting. Osei (2016) indicates that the demand for money function is used as a means of identifying medium term growth targets for money supply and as a way of manipulating the interest rate and reserve money to aid in controlling liquidity in the economy and also inflation. Inflation targeting depends to a large extent on the interest rate channel to transmit monetary policy (Hammond, 2012). Driscoll and Lahiri (1983) and Khan (1980) have argued that domestic interest rate is not a relevant determinant of money demand in developing countries and that the relevant determinants are real income, the rate of inflation and some external opportunity cost variable. Two main facts have been used to justify the exclusion of domestic interest rate as determinant of money demand in developing countries like Ghana. First, financial assets are either absent or inadequate and thus the choice of asset holding is limited to money or real goods. Second, domestic interest rate may show little variation over time as a result of government regulation.

But, in 1992, Simmons Simmons states that financial liberalization and developments since the 1970s have made the arguments of excluding domestic interest rate in money demand functions for developing economies less relevant. In his study on five African countries (Congo, Cote d'Ivoire, Mauritius, Morocco and Tunisia), Simmons (1992) finds that in Cote d'Ivoire, Mauritius and Morocco, domestic interest rate has a significant influence on demand for money (M1) balances in the long run. Sichei and Kamau (2012) in Kenya, Nduka et al. (2013) and Ogbonna (2015) in Nigeria have also shown that interest rate has negative and significant influence on demand for money.

In the Ghanaian context, Kallon (1992) argues that as financial intermediation improves in the country, the asset-swapping process is strengthened, and thus making the Ghanaian money demand more interest rate sensitive. Yet, Dagher and Kovanen (2011), Havi et al. (2014) and Osei (2016) examine determinants of money demand in Ghana and find that interest rate has no effect on demand for money. The evidence in Ghana regarding the influence of interest rate on demand for money does not appear to support that of Nigeria, Cote d'Ivoire, Kenya and other sub-Sahara Africa 
countries with similar economic and social characteristics. However, these and other African countries together pursue financial liberalization policies in the early 1980s. Therefore, having different results regarding domestic interest rate and demand for money relations justifies the need for further studies.

This paper seeks to investigate whether interest rate has influence on demand for broad money (M2+) in Ghana using annual time series data from 1980-2016. The current paper is expected to contribute to the debate regarding demand for money determinants and also to ascertain the effect of interest rate on demand for money in Ghana. The outcome of this study is also expected to aid in the formulation and implementation of monetary policy in Ghana and other sub-Saharan African countries with similar characteristics.

The rest of the paper is arranged as follows. Section 2 reviews and discusses empirical studies which underpin the present study. Section 3 is the methodology and specifically we present model specification, data and the estimation strategies. Section 4 focuses on the analysis and presentation of the empirical results and the discussions whilst Section 5 concludes the study.

\section{Literature Review}

Many studies have investigated the determinants and stability of money demand in developing countries. Some have included domestic interest rate as explanatory variable (see for example, Dagher \& Kovanen, 2011; Budha, 2012; Sichei \& Kamau, 2012; Nduka et al., 2013; Ogbonna, 2015; Osei, 2016) whilst others do not (see for instance, Mannah-Blankson \& Belnye, 2004; Bahmani-Oskooee \& Gelan, 2009; Samimi, Kenari, \& Ghajari, 2013; Bahmani-Oskooee \& Bahmani, 2015). The findings of these studies have been diverse.

Sichei and Kamau (2012) examine demand for money and its implication for the conduct of monetary policy in Kenya. The study uses quarterly data from 1997Q4 to 2011Q2 and vector autoregression (VAR) is employed as the estimation technique. Sichei and Kamau (2012) find that, real income and deposit rate have positive and significant effect on demand for money. The study also reveals that Treasury bill rate and inter-bank rate are negatively correlated with demand for money and are statistically significant.

Budha (2012) investigates the determinants of demand for money in Nepal using annual data from 1975 to 2011. The long run results from the autoregressive distributed lag (ARDL) model reveal that real income, inflation, and interest rate have no significant influence on demand for money. However, the short run result shows a negative and significant relationship between inflation and demand for money. As regards the stability of demand for money over the study period, the cumulative sum and cumulative sum of squares plots indicate that demand for money in Nepal is stable.

In a related study, Nduka et al. (2013) and Ogbonna (2015) examine the determinants of demand for money and its stability in Nigeria. Nduka et al. (2013) use annual time series data covering the period 1986 to 2011 and the authors employ bounds testing cointegration within the framework of autoregressive distributed lag (ARDL) model as estimation technique. The results show that there is a positive and significant relationship between income and demand for money. Nduka et al. (2013) further show that interest rate and inflation have negative and significant impact on demand for money. Demand for money is found to be stable over the study period as revealed by the cumulative sum and cumulative sum of squares plots. On the other hand, Ogbonna (2015) applies Johansen cointegration and vector error correction model to monthly data covering the period 2005 to 2013. The results show that, interest rate and exchange rate are negatively related to demand for 
money. However, inflation has a positive correlation with demand for money. On stability, the study reveals that demand for money in Nigeria is stable over the study period.

Mall (2013) also examines the function of real demand for money in Pakistan. Annual time series data spanning the period 1973 to 2010 is employed and bounds testing approach to cointegration used. The explanatory variables include real income, exchange rate and deposit rate. The study reveals that real income and exchange rate have positive influence on demand for money but the relationship between the deposit rate and demand for money is negative. In Turkey, Özçalık (2014) uses monthly data from 1995Q4 to 2013Q3 and applies ARDL to examine the determinants of demand for money. The variables considered include interest rate, GDP (proxy for income), and exchange rate. The estimates show that there is a positive relationship between interest rate, income and demand for money. The results also show a positive relationship between exchange rate and demand for money though insignificant. Similarly, Aggarwal (2016) investigates the determinants of demand for money in India using quarterly data spanning from 1996 to 2013. The study shows that there is a positive and significant relationship between GDP, interest rate and demand for money. Nyumuah (2017) investigates the relationship between demand for money and interest rate for eight African countries including Angola, Gambia, Kenya, Mali, Nigeria and Uganda. Panel data spanning the period 1998 to 2012 is employed and random and fixed effect as well as fully modified ordinary least squares are used as estimation techniques. The results from the estimations show that there is a positive relationship between income and demand for money and a negative relationship between inflation, interest rate and demand for money. Interest rate and income variables are statistically insignificant in all the models but that of inflation is statistically significant.

In Ghana, studies on determinants of demand for money are limited (MannahBlankson \& Belnye, 2004; Dagher \& Kovanen, 2011; Havi et al., 2014; Osei, 2016). In 2011, Dagher and Kovanen apply bounds testing approach to cointegration to quarterly data (1990Q1 to 2009Q4) to examine the determinants of demand for money and also test for its stability. The dependent variable is measured by broad money $(\mathrm{M} 2+)$ whilst the independent variables include inflation, real income, interest rate and exchange rate. The study shows that there is a positive relationship between real income and demand for money. The interest rate and inflation variables are found not to have any significant influence on demand for money. As regards the exchange rate variable, the results reveal that it has negative and significant effect on demand for money and thus confirming the importance of currency substitution and valuation effects. The cumulative sum and cumulative sum of squares plots reveal that demand for money is stable over the study period.

Havi et al. (2014) examine the determinants of demand for money using annual time series data from 1970 to 2011. The results from the vector error correction model reveal that real income, exchange rate, interest rate are positively related to demand for money but not statistically significant. Foreign interest rate is revealed to have a negative and significant relationship with demand for money. The cumulative sum and cumulative sum of squares plots also indicate that demand for money is stable over the period under consideration. Similarly, Osei (2016) investigates the determinants of demand for broad money (M2+) for the period 1991Q1 to 2014Q4. The author employs Johansen cointegration approach for the analysis. The results show that there is a positive and significant relationship between demand for money and real GDP (proxy for income). The study however does not find significant 
relationship between interest rate, exchange rate and demand for money. As regards Mannah-Blankson and Belnye (2004), the variables of interest are financial innovation and real income and the control variables are exchange rate and inflation rate. Interest rate is not considered in the study. The results reveal that income, inflation, exchange rate and financial innovation have influence on the demand for M1 in the long run whilst income, inflation and innovation have effect on the demand for M2.

Dagher and Kovanen (2011), Havi et al. (2014) and Osei (2016) do not find any statistically significant effect of interest rate on demand for money and this suggests that financial market does not play important role in the public's financial decisions considering the study period.

As mentioned earlier, Bahmani-Oskooee and Gelan (2009), Samimi et al. (2013), Bahmani-Oskooee and Bahmani (2015) do not consider interest rate as explanatory variable in their studies. Bahmani-Oskooee and Gelan (2009) investigate the determinants of demand for money and its stability in 21 African countries using quarterly data from 1971Q1 to 2004Q3. The explanatory variables are real income, inflation and exchange rate. The bound testing approach to cointegration within the autoregressive distributed lag (ARDL) model is applied to the data set. Bahmani-Oskooee and Gelan (2009) show that real income has positive effect on demand for money. The study also reveal that inflation and exchange rate are negatively related to demand for money. The cumulative sum (CUSUM) and cumulative sum of squares (CUSUMSQ) plots also reveal that money demand is stable over the study period.

Also, Samimi et al. (2013) examine the relationship between exchange rate and demand for money in Iran using quarterly data from 1990Q2 to 2013Q1. The other explanatory variables included in the model are real GDP (proxy for income) and inflation. The authors employ generalized method of moments (GMM) as the estimation technique. The results indicate that there is a positive relationship between income and demand for money. A negative relationship between inflation and demand for money is also reported. As regards exchange rate which is the variable of interest, Samimi et al. (2013) reveal that it is negatively related to demand for money.

Bahmani-Oskooee and Bahmani (2015) apply nonlinear ARDL estimation technique to examine demand for money in Iran using quarterly data. The results show that there is a positive relationship between real income and demand for money which is consistent with theory and past studies. The study further shows that there is a negative relationship between inflation, exchange rate and demand for money though the effect of exchange rate is insignificant.

\section{Methodology}

This section presents the methodological framework of the study and has three parts. The first part presents the model specification whereas the second and third parts focus on data and estimation strategy.

\subsection{Model specification}

We follow past studies by Osei (2016), Bahmani-Oskooee and Bahmani (2015), Bahmani-Oskooee and Gelan (2009) and specify the demand for broad money (M2+) function as follows:

$$
M=f(Y, I N T R, I N F, E R)
$$

where $\mathrm{M}$ is real money demand, $\mathrm{Y}$ is real income capturing the transaction and precaution motive for money demand, INTR is interest rate which captures the returns on alternative to money and also the speculative motive for money demand, INF is inflation and captures the opportunity cost of holding money and ER is exchange rate measuring currency substitution with $\mathrm{f}$ denoting the functional form. The estimable form of 
equation (1) is given by equation (2).

$$
\begin{gathered}
\ln M=a+\beta \ln Y_{t}+ \\
\gamma \ln I N T R_{t}+\delta \ln I N F_{t}+\phi E R_{t}+\varepsilon_{t}
\end{gathered}
$$

where M, Y, INTR, INF, ER are as explained earlier in equation (1). The symbol $\alpha$ represents the constant term and $\varepsilon$ is the stochastic disturbance term of the equation such that $\varepsilon_{t} \sim N\left(0, \sigma^{2}\right)$. The parameters $\beta, \gamma$, $\delta$ and $\phi$ are the coefficients of income, interest rate, inflation and exchange rate respectively. The subscript $\mathrm{t}$ and $\mathrm{ln}$ denote time trend and natural logarithm accordingly.

\subsection{Data and variable description}

This paper uses annual time series data from 1980 to 2016. The dependent variable is real money demand (M) and measured by dividing broad monetary aggregate $(\mathrm{M} 2+)$ by the consumer price index (CPI). Bahmani-Oskooee and Bahmani (2015) have also operationalized the dependent variable by the same approach.

The independent variables include interest rate, income, inflation and exchange rate. Data for broad money, income, inflation and exchange rate are sourced from the World Bank's World Development Indicators (WDI) (2017). Data on interest rate is obtained from Bank of Ghana files. The income $(\mathrm{Y})$ variable is measured by dividing nominal gross domestic product by GDP deflator in decimals to obtain the real value. Income is expected to be positive, $\beta>0$. Interest rate (INTR) is proxied by 91-day Treasury bill rate and is expected to be negative, $\gamma<0$. That is, when interest is high the opportunity cost of holding cash rises and therefore the rational individual will hold less money all other things being equal. Inflation (INF) variable is measured by consumer prices (annual rate). The relationship between inflation and money demand is expected to be either positive or negative. When inflation rises, it implies individuals' purchasing power has reduced and to maintain the same level of consump- tion more money has to be demanded ceteris paribus given the positive relationship, $\delta>0$. On the other hand, if inflation is high it also means that cost of holding cash has risen and therefore individuals will not like to hold more cash but rather hold money in the form of physical assets. This therefore reduces real money balances resulting in the negative relationship and hence $\delta<0$.

The price of the US dollar in Ghanaian Cedi is used as a measure for exchange rate in this study. It is expected to have a negative relationship with money demand. If exchange rate increases the value of the domestic currency reduces and that of the foreign country increases. This further implies that the value of foreign assets has risen and therefore individuals will prefer to hold more of foreign assets or currency and less of domestic currency all other things being equal yielding the negative relationship, $\phi<0$.

\subsection{Estimation strategy}

The present study employs the autoregressive distributed lag (ARDL) model bounds test for cointegration following M. H. Pesaran et al. (2001) and the error correction model (ECM) for the analyses. The use of ARDL is because of the relatively small number of observations (1980-2016). Also, the ARDL is deemed appropriate for the study given that it is able to make use of series that are strictly integrated of order zero $[I(0)]$, order one $[I(1)]$ or mix, on the condition that the series are not integrated of order two $[I(2)]$ or more (Obeng et al., 2018). The Augmented Dickey-Fuller (ADF) test by Dickey and Fuller (1979, 1981), the non-parametric Phillips-Perron (P-P) test by Phillips and Perron (1988) and the Kwaitkowski-PhillipsSchmidt-Shin (KPSS) by Kwiatkowski et al. (1992) are used for the unit root test. The KPSS test differs from the traditional ADF test and the P-P test in terms of how the null hypothesis is stated. The null hypothesis of 
the KPSS test states that the series are stationary whereas those of ADF and P-P tests state that the series have unit root. The null hypothesis of stationarity for the KPSS test is rejected if the test statistic is greater than the critical value at an acceptable level of significance (not more than 10 percent).

After establishing the stationarity properties of the variables in equation (2), we first estimated a conditional error correction model (ECM) in OLS form. The ARDL form of equation (2) is specified in equation (3) which provides both the short-and long run estimates in one single estimation.

$$
\begin{gathered}
\triangle \ln M_{t}=\beta_{0}+\sum_{i=1}^{v} \phi_{i} \Delta \ln M_{t-i}+ \\
\sum_{i=1}^{w} \gamma_{i} \Delta \ln Y_{t-i}+\sum_{i=1}^{x} \theta_{i} \Delta \ln I N T R_{t-i}+ \\
\sum_{i=1}^{y} \delta_{i} \triangle \ln I N F_{t-i}+\sum_{i=1}^{z} \rho_{i} \triangle \ln E R_{t-i}+ \\
\alpha_{0} \ln M_{t-1}+\alpha_{1} \ln Y_{t-1}+ \\
\alpha_{2} \ln I N T R_{t-1}+\alpha_{3} \ln I N F_{t-1}+ \\
\alpha_{4} \ln E R_{t-1}+\mu_{t}
\end{gathered}
$$

where, $\triangle$ is the first difference operator and the variables $\mathrm{M}, \mathrm{Y}, \mathrm{INTR}, \mathrm{INF}$ and ER are those explained earlier in equation (1). $\beta_{0}$ is the drift component, $\mu_{t}$ is the usual white noise residuals and $v, w, x, y$ and $z$ represent the lag length for the respective variables. The coefficients of the short-run estimation are $\phi_{i}, \gamma_{i}, \theta_{i}, \delta_{i}$ and $\rho_{i}$ and the long-run coefficients are $\alpha_{i} s(i=0,1,2,3,4)$. However in order to have a valid long-run estimates, we follow M. H. Pesaran et al. (2001) and use $\mathrm{F}$ test for joint significance of the lagged level variables incorporated in equation (3) which follows a non-standard distribution. Equations (4) and (5) represent the null and the alternative hypotheses respectively.

$$
\begin{aligned}
& H_{0}: \beta_{1}=\beta_{2}=\beta_{3}=\beta_{4}=\beta_{5}=0 \\
& H_{1}: \beta_{1} \neq \beta_{2} \neq \beta_{3} \neq \beta_{4} \neq \beta_{5} \neq 0
\end{aligned}
$$

M. H. Pesaran et al. (2001) provide two sets of critical values; lower bound and upper bound. The lower and upper bound critical values assume that all the variables are $I(0)$ and $I(1)$ respectively. The null hypothesis of no cointegration is rejected in favour of the alternative hypothesis of cointegration if the calculated F-statistic is greater than the appropriate upper bound critical value. On the other hand, the null hypothesis is not rejected if the calculated $\mathrm{F}$-statistic value is below the lower bound implying no cointegration. Lastly, the results become inconclusive if the calculated F-statistic lies within the lower and upper bound critical values. When cointegration among the variables is established, the short- and long run coefficients can then be estimated using the appropriate optimal lag structure. B. Pesaran and Pesaran (2010) suggest that the appropriate optimal lag structure is selected using the Schwartz Bayesian Criterion (SBC) because it provides more parsimonious specification of the model especially in relatively small samples.

\section{Empirical Results and Discussion}

In this section we present and discuss the empirical results of the study. We start with the discussion of the unit root results and the cointegration test. The next is the discussion of the long-and short run estimates as well as the fitness of the model, reliability and stability tests.

\subsection{Unit root and cointegration test re- sults}

\subsubsection{Unit root test results}

The unit root test results from the ADF and $\mathrm{P}-\mathrm{P}$ tests are reported in Table 1 whereas that of the KPSS is reported in Table 2. The results from both $\mathrm{ADF}$ and $\mathrm{PP}$ tests indicate that the variables in equation (2) are integrated of order zero and one $[I(0)$ and $I(1)]$. Specifically, the test from both ADF and P$\mathrm{P}$ show that inflation $(\ln I N F)$ is integrated of order zero $[I(0)]$ and the remaining vari- 
Table 1: Unit root test results (ADF and P-P)

\begin{tabular}{lcccccccc} 
Variable & \multicolumn{4}{c}{ ADF Test } & \multicolumn{3}{c}{ Level } & \multicolumn{3}{c}{ PP Test } \\
& \multicolumn{2}{c}{ Level } & \multicolumn{2}{c}{ First Difference } & Difference \\
\hline LnM & Trend & No Trend & Trend & No Trend & Trend & No Trend & Trend & No Trend \\
\hline LnY & 1.379 & -0.949 & $-4.879^{* * *}$ & $-5.462^{* * *}$ & 0.817 & -1.066 & $-4.983^{* * *}$ & $-5.462^{* * *}$ \\
LnINTR & 2.063 & -1.888 & $-4.372^{* * *}$ & $-5.714^{* * *}$ & 3.138 & -1.252 & $-4.354^{* * *}$ & $-5.702^{* * *}$ \\
LnINF & -2.679 & -2.366 & $-7.792^{* * *}$ & $-7.853^{* * *}$ & -2.618 & -2.183 & $-8.163^{* * *}$ & $-9.338^{* * *}$ \\
ER & $-4.012^{* * *}$ & $-4.860^{* * *}$ & $-6.257^{* * *}$ & $-6.287^{* * *}$ & $-4.021^{* * *}$ & $-4.901^{* * *}$ & $-10.158^{* * *}$ & $-10.742^{* * *}$ \\
\hline
\end{tabular}

Source: Authors' estimation using data from World Bank's World Development Indicators.

Source: Authors' estimation using data from World Bank's World Development Indicators.
Note: *** denotes the rejection of the null hypothesis of unit root at 1 percent level of significance.

ables: broad monetary aggregate $(\ln M)$, real income $(\ln Y)$, interest rate $(I N T R)$, and exchange rate (ER) are integrated of order one $[I(1)]$. The results from the KPSS also indicate that the series are stationary at level and therefore integrated of order zero $[I(0)]$. This is because, none of the KPSS test statistic is greater than the critical values at the 1 percent significance level the study selects. These results obtained support the use of the ARDL bounds test approach to ascertain the existence or otherwise of long run relationship among the variables.

\subsubsection{Cointegration test results}

The results from the cointegration test using the autoregressive distributed lag bounds test for long run relationship among the dependent and independent variables are reported in Table 3. The selection of the optimal lag for the ARDL $(1,0,0,1,0)$ is based on the Schwartz Bayesian Criterion (SBC) as mentioned earlier under section 3.3 .

From Table 3, it is evident that the Fstatistic of 6.497 is greater than the upper bound critical value of 5.06 at 1 percent significance level hence the rejection of the null hypothesis of no long run relationship between the dependent and the independent variables. It is therefore concluded that the variables in equation (2) are cointegrated and hence valid long run coefficients can be estimated.

\subsection{Estimated long-and short run re- sults using the ARDL approach}

Table 4 presents the estimated long run regression results. The variable of interest
Table 2: Unit root test results (KPSS)

\begin{tabular}{lcccc} 
Variable & \multicolumn{2}{c}{ Level } & \multicolumn{2}{c}{ First Difference } \\
& Trend & No Trend & Trend & No Trend \\
\hline LnM & 0.206 & 0.699 & 0.081 & 0.433 \\
& $(0.216)$ & $(0.739)$ & $(0.216)$ & $(0.739)$ \\
LnY & 0.199 & 0.713 & 0.128 & 0.483 \\
& $(0.216)$ & $(0.739)$ & $(0.216)$ & $(0.739)$ \\
LnINTR & 0.152 & 0.156 & $0.428^{* * *}$ & 0.293 \\
& $(0.216)$ & $(0.739)$ & $(0.216)$ & $(0.739)$ \\
LnINF & 0.089 & 0.680 & 0.212 & 0.213 \\
& $(0.216)$ & $(0.739)$ & $(0.216)$ & $(0.739)$ \\
ER & 0.195 & 0.714 & 0.138 & 0.559 \\
& $(0.216)$ & $(0.739)$ & $(0.216)$ & $(0.739)$ \\
\hline
\end{tabular}

Source: Authors' estimation using data from World Bank's World Development Indicators.

efthe null hypothesis of sta-

Table 3: ARDL bounds test results for long run relationship

\begin{tabular}{lcc} 
Test Statistic & $\begin{array}{l}\text { Lower bound } \\
\text { critical value }\end{array}$ & $\begin{array}{c}\text { Upper bound } \\
\text { critical value }\end{array}$ \\
\hline $6.497^{* * *}$ & 3.74 & 5.06 \\
\hline $\begin{array}{l}\text { Source: Authors' estimation using data from World Bank's } \\
\text { World Development Indicators. } \\
\text { Note: *** denotes the rejection of the null hypothesis of no } \\
\text { cointegration at 1 percent level of significance. }\end{array}$
\end{tabular}

is the rate of interest and the coefficient is positive but statistically insignificant. This suggests that interest rate has no influence on demand for money in Ghana considering the period of study. Our finding corroborates past studies on Ghana (see: Dagher \& Kovanen, 2011; Havi et al., 2014; Osei, 2016). These authors report statistically insignificant relationship between interest rate and demand for money. In addition, a study by Nyumuah (2017) on eight African countries including Nigeria, Gambia, Angola, Mali and Uganda reveals that interest rate has no influence on demand for money. Our finding also confirms the argument of 
Friedman (1956) that interest rate is not an important determinant of demand for money and that demand for money is interest rate inelastic.

The insignificant relationship between interest rate and demand for money could be explained by the low degree of monetization in Ghana. In 2015, World Bank indicates that financial literacy in Ghana is low and this does not encourage speculative purposes for money demand (Xu \& Zia, 2012). This therefore arouses the urgent need to enhance the financial literacy level of Ghanaians as indicated in past studies (see for example, Baidoo et al., 2018; Baidoo \& Akoto, 2019). Another important variable is real income.

Table 4: Estimated long-run results Regressor Coefficient Std. Err. t-Stat. p-value

\begin{tabular}{lllll}
\hline LnY & 1.452 & 0.371 & 3.919 & 0.001
\end{tabular}

$\begin{array}{lllll}\text { LnINTR } & 0.039 & 0.140 & 0.277 & 0.784\end{array}$

$\begin{array}{lllll}\text { LnINF } & -0.612 & 0.416 & -1.471 & 0.153\end{array}$

$\begin{array}{lllll}\mathrm{ER} & 0.127 & 0.103 & 1.237 & 0.227\end{array}$

$\begin{array}{lllll}\text { Constant } & -8.487 & 4.426 & -1.917 & 0.066\end{array}$

Source: Authors' estimation using data from World Bank's Note: $\ln \mathrm{M}$ is the dependent variable.

The coefficient indicates income elasticity of 1.45 and statistically significant at the 1 percent level, suggesting that money is a luxury good in Ghana. This finding is consistent with the a priori expectation and economic theory (see Fisher, 1911; Keynes, 1936; Friedman, 1956; Valadkhani, 2008). Past studies have also reported similar findings (see Simmons, 1992; Bahmani-Oskooee \& Gelan, 2009; Dagher \& Kovanen, 2011; Sichei \& Kamau, 2012; Bahmani-Oskooee \& Bahmani, 2015; Osei, 2016). For example, Simmons (1992) finds that Cote d'Ivoire and Morocco have income elasticities of 1.49 and 1.43 respectively. Our elasticity coefficient is greater than unity and thus consistent with Friedman's assertion that income elasticity of demand for money is not equal to unity but rather greater than one making it the main determinant of money demand.

With regard to inflation and exchange rate variables, Table 4 shows that inflation and exchange rate have negative and positive effect on demand for money respectively but the effect is statistically insignificant. This implies that in Ghana inflation and exchange rate have no influence on demand for money considering the period of study. Previous studies such as Bahmani-Oskooee and Bahmani (2015) on Iran and Osei (2016) on Ghana also show that exchange rate has no effect on demand for money. Dagher and Kovanen (2011) reveal that inflation has an insignificant impact on demand for money in Ghana.

The short run results are reported in Table 5 and the signs are not statistically different from those obtained from the long run estimation. For example, the interest rate variable has positive and insignificant impact on demand for money. The results further show that real income and exchange rate have positive but statistically insignificant effect on demand for money in the short run. These findings suggest that real income influences demand for money only in the long run.

Contrary to the long run result, the coefficient for the inflation is statistically significant at 1 percent level but the negative relationship is maintained. Thus, in the short run, inflation affects demand for money negatively and this is consistent with theory and past studies (see for instance, Mannah-Blankson \& Belnye, 2004).

In the Ghanaian context, people will prefer to hold their wealth in foreign currencies such as US Dollar, British Pound and the Euro or in the form of physical assets like buildings and cars when inflation is high, hence influencing demand for money negatively. Our result contradicts that of Havi et al. (2014) who report a positive and significant relationship between demand for money and inflation for Ghana. However, other past studies have reported a negative and significant relationship between demand for money and inflation (see Bahmani-Oskooee \& Gelan, 2009; Budha, 2012; Sichei \& Kamau, 2012; Nduka et al., 2013; Bahmani-Oskooee \& Bahmani, 2015; 
Nyumuah, 2017). The error correction term

Table 5: Estimated short-run results

\begin{tabular}{lcccc} 
Regressor & Coefficient & Std. Err. & t-Stat. & p-value \\
\hline$\triangle \ln M(-1)$ & 0.414 & 0.162 & 2.551 & 0.017 \\
$\triangle \ln Y$ & 0.468 & 0.307 & 1.526 & 0.139 \\
$\triangle \ln I N T R$ & 0.013 & 0.041 & 0.301 & 0.766 \\
$\triangle \ln I N F$ & -0.213 & 0.041 & -5.190 & 0.000 \\
$\triangle \ln I N F(-1)$ & 0.066 & 0.026 & 2.561 & 0.017 \\
$\triangle \mathrm{ER}$ & 0.041 & 0.028 & 1.445 & 0.161 \\
$\mathrm{ecm}(-1)$ & -0.322 & 0.142 & -2.275 & 0.031 \\
$R^{2}$ & 0.997 & & & \\
$\mathrm{Adj} R^{2}$ & 0.996 & & & \\
$\mathrm{DW}$ & 2.162 & & & \\
F-statistic & 931.421 & & & \\
Prob.(F-stat.) & 0.000 & & & \\
\hline Source: Authors' estimation using data & from & World & Bank's \\
World Development Indicators. & & & \\
Note: InM is the dependent variable. & & &
\end{tabular}

is negative and significant confirming the long run relationship between real income, interest rate, inflation, exchange rate and demand for money as well as restoration to long run equilibrium when there is a short run shock in any of the independent variables. Specifically, the error correction term, ECM $(-1)$ of -0.32 indicates that long run equilibrium will be restored at a speed of approximately 32 percent each year after a shock. The coefficient of determination reported in Table 5 shows that approximately about 99 percent of the variations in demand for money is explained by the independent variables: real income, interest rate, inflation and exchange rate. The probability value also indicates that the estimated model is good and well fitted.

\subsection{Model diagnostics and reliability tests results}

The validity of the results from the ARDL is dependent on the assumption that the model is free from any statistical problem. To this end, several diagnostic tests on the model including normality, serial correlation, heteroskedasticity, functional form, cumulative sum (CUSUM) and cumulative sum of squares (CUSUMSQ) have been conducted and the results are reported in Table 6 . The normality and serial correlation tests were conducted using the Jarque-Bera test and the Breusch-Godfrey LM test respectively. Heteroskedasticity and functional form tests were also done using BreuschPagan-Godfrey test and Ramsey reset test respectively. Lastly, the stability of the model over the sample period is ascertained from the plots of CUSUM and CUSUMSQ.

Table 6: Diagnostic test results

\begin{tabular}{lcc} 
Diagnostic test & Test Statistic & Prob. value \\
\hline Normality & 1.120 & 0.571 \\
Serial Correlation & 0.835 & 0.446 \\
Heteroskedasticity & 0.648 & 0.731 \\
Functional form & 0.307 & 0.762 \\
CUSUM & Stable & \\
CUSUMQ & Stable \\
\hline Source: Authors' estimation using data from World Bank's
\end{tabular}
World Development Indicators.

From the results in Table 6, it is evident that the estimated model is free from the above mentioned econometric problems since the probability values are greater than 0.05 . The results is also not spurious which is confirmed by the negative and statistically significant error correction term and the existence of long run cointegration. The CUSUM and CUSUMSQ graphs in Figure 1 also indicate that demand for money over the sample period is stable. This is so because, the plots of cumulative sum and cumulative sum of squares (CUSUM and CUSUMSQ) lie within the 5 percent critical bounds.

\section{Conclusions and Policy Implications}

This paper has investigated the effect of interest rate on demand for money in Ghana using annual time series data from the period 1980 to 2016. In order to achieve the objective of the study, bounds testing approach to cointegration within the framework of autoregressive distributed lag (ARDL) and the error correction model which are appropriate for relatively small sample size and mixture of integration order of variables: order zero and one, $[I(0)$ and $I(1)]$ have been employed as estimation techniques. The dependent variable is demand for money and the independent variables incorporated in the model are real income, interest rate, inflation and 


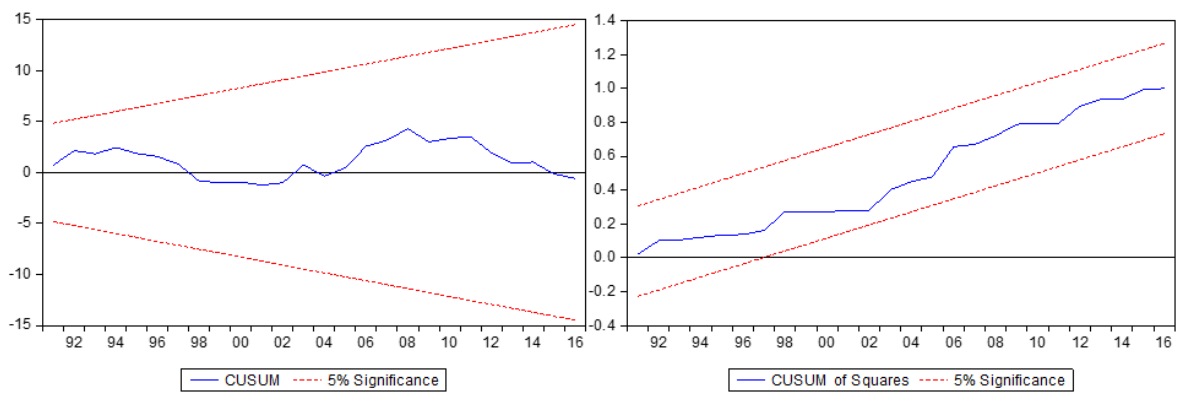

Figure 1: Plots of CUSUM and CUSUMSQ

Source: Authors' construction using data from World Bank's World Development Indicators

exchange rate.

The short-and long run results indicate that interest rate has insignificant effect on demand for money. Further, the long run results reveal that there is a positive and significant relationship between real income and demand for money whereas inflation and exchange rate are insignificant. Regarding the short run estimations, the paper reveals that inflation significantly influences demand for money negatively whilst real income and exchange rate do not influence demand for money. The paper therefore concludes that interest rate does not influence demand for money in Ghana. It is also concluded that, the factors that influence demand for money in Ghana are real income and inflation, and also demand for money over the study period is stable.

This paper has some important policy implications for developing countries especially Ghana. First, given that demand for money is interest rate inelastic, the study recommends that monetary authorities should not focus much on interest rate when designing monetary policies that are geared towards stabilizing the economy to expedite economic growth. Second, following the significant relationship between income and inflation revealed by the study, it is recommended that monetary authorities should focus more on these variables when designing monetary policies aimed at stabilizing the economy and enhancing economic growth. In addition, the plots of the cumulative sum and cumulative sum of squares in the present study have revealed a stable demand for money function. The implication of this stable money demand function is that policy makers in Ghana and other developing economies who exhibit similar characteristics with Ghana can still make use of the monetary policies to alter the economy towards achieving economic growth and subsequently economic development.

\section{References}

Aggarwal, S. (2016). Determinants of money demand for India in presence of structural break: An empirical analysis. Business and Economic Horizons, 12(4), 173-177. doi:10.15208/beh.2016.13

Bahmani-Oskooee, M., \& Bahmani, S. (2015). Nonlinear ardl approach and the demand for money in Iran. Economics Bulletin, 35(1), 381-391. http://www . accessecon. com/Pubs/EB/ 2015/Volume35/EB-15-V35-I1-P42.pdf.

Bahmani-Oskooee, M., \& Gelan, A. (2009). How stable is the demand for money in African countries? Journal of Economic Studies, 36(3), 216235. doi:10.1108/01443580910983825

Baidoo, S. T., \& Akoto, L. (2019). Does trust in financial institutions drive formal saving? empirical evidence from Ghana. International Social Science Journal, O(0). doi:10.1111/issj.12200

Baidoo, S. T., Boateng, E., \& Amponsah, M. (2018). Understanding the determinants of saving in Ghana: Does financial literacy matter? Journal of International Development, 30(5), 886903. doi:10.1002/jid.3377

Bank of Ghana. (2017). Monetary time series data (Tech. Rep.). https://www.bog.gov.gh/ statistics/time-series-data.

Budha, B. B. (2012). Demand for money in Nepal: An ARDL bounds testing approach. International Social Science Journal, 25(1), 2136. https://www.nrb.org.np/ecorev/pdffiles/ 
vol25-1_art2.pdf.

Dagher, J. C., \& Kovanen, A. (2011). On the stability of money memand in Ghana; a bounds testing approach (IMF Working Papers). International Monetary Fund. https://ssrn.com/ abstract $=1974841$.

Dickey, D. A., \& Fuller, W. A. (1979). Distribution of the estimators for autoregressive time series with a unit root. Journal of the American statistical association, 74(366a), 427-431. doi:1080/01621459.1979.10482531

Dickey, D. A., \& Fuller, W. A. (1981). Likelihood ratio statistics for autoregressive time series with a unit root. Econometrica, 49(4), 1057-1072. doi:10.2307/1912517

Driscoll, M. J., \& Lahiri, A. K. (1983). Incomevelocity of money in agricultural developing economies. The Review of Economics and Statis tics, 65(3), 393-401. doi:10.2307/1924184

Fisher, I. (1911). The purchasing power of money. New York: Macmillan.

Friedman, M. (1956). The quantity theory of money: a restatement. In M. Friedman (Ed.), Studies in the quantity theory of money. Chicago: Chicago University Press.

Goldfeld, S. M. (1989). Demand for money: empirical studies. In J. Eatwell, M. Milgate, \& P. Newman (Eds.), Money. London: Palgrave Macmillan UK. doi:10.1007/978-1-349-19804-7_14

Goldfeld, S. M., \& Sichel, D. E. (1990). The demand for money. In B. M. Friedman (Ed.), Handbook of monetary economics. Elsevier. doi:10.1016/S1573-4498(05)80011-6

Hammond, G. (2012). State of the art of inflation targeting. London: Centre for Central Banking Studies, Bank of England. https://www.bankofengland.co.uk/ -/media/boe/files/ccbs/resources/ state-of-the-art-inflation-targeting.

Havi, E. D. K., Enu, P., \& Opoku, C. (2014). Demand for money and long run stability in Ghana: Cointegration approach. European Scientific Journal, ESJ, 10(13). http://eujournal.org/ index.php/esj/article/download/3372/3136.

Kallon, K. M. (1992). An econometric analysis of money demand in Ghana. The Journal of Developing Areas, 26(4), 475-488. http://www.jstor . org/stable/4192135.

Keynes, J. M. (1936). The general theory of employment, interest and money. London: Macmillan.

Khan, M. S. (1980). Monetary shocks and the dynamics of inflation. IMF Economic Review, 27(2), 250-284. https://www.jstor.org/ stable/pdf/3866713.pdf.

Kumo, W. L. (2015). Inflation targeting monetary policy, inflation volatility and economic growth in South Africa (Working Paper Series No. 216). African Development Bank. https:// ideas. repec . org/p/adb/adbwps/2154.html.

Kwakye, J. K. (2012). Key issues in the choice of an appropriate monetary policy framework for Ghana. Ghana: Institute of Economic Affairs
(IEA). http://ieagh.org/wp-content/uploads/ 2014/07/mono-32.pdf.

Kwiatkowski, D., Phillips, P. C., Schmidt, P., \& Shin, Y. (1992). Testing the null hypothesis of stationarity against the alternative of a unit root: How sure are we that economic time series have a unit root? Journal of Econometrics, 54 (1), 159-178. doi:10.1016/0304-4076(92)90104-Y

Mall, S. (2013). Estimating a function of real demand for money in Pakistan: An application of bounds testing approach to cointegration. International Journal of Computer Applications, $79(5)$. https://pdfs.semanticscholar.org/92dc/ a24ca48095d56b60ac7da3385599b0487cbf .pdf.

Mannah-Blankson, T., \& Belnye, F. (2004). Financial innovation and the demand for money in Ghana (Tech. Rep. No. 2004-08). Bank of Ghana, Accra. https://www.bog.gov.gh/ privatecontent/Publications/Staff_Working Papers/2004/wp-08.pdfl.

Mohammed, A., Hadrat, Y., \& Emmanuel, B. (2016). Inflation targeting and economic growth in Ghana: an empirical investigation. Ghanaian Journal of Economics, 4(1), 158-177. https://journals.co.za/content/journal/ 10520/EJC-5754f c04c?crawler=true\&mimetype $=$ application/pdf

Nduka, E. K., Chukwu, J. O., \& Nwakaire, O. N. (2013). Stability of demand for money in Nigeria. Ghanaian Journal of Economics, 3(4), 1-11. https://journals.co.za/content/journal/ 10520/EJC-5754f c04c? crawler=true\&mimetype= application/pdf.

Nyumuah, F. S. (2017). An investigation into the interest elasticity of demand for money in developing countries: A panel data approach. International Journal of Economics and Finance, 9(3), 69-80. doi:10.5539/ijef.v9n3p69

Obeng, S. K., Akoto, L., \& Acquah, F. (2018). Democracy, globalization and private investment in Ghana. Global Business Review, 19(1), 1-20. doi:10.1177/0972150917713288

Ogbonna, B. C. (2015). Exchange rate and demand for money in Nigeria. Research in Applied Economics, 7(2), 21-37. doi:10.5296/rae.v7i2.7916

Osei, V. (2016). Estimating money demand for Ghana. International Journal of Developing and Emerging Economies, 4(2), 28-43. http:// www . eajournals.org/wp-content/uploads / Estimating-Money-Demand-for-Ghana.pdfl.

Özçalık, M. (2014). Money demand function in Turkey: An ARDL approach. Sosyal Ekonomik Araştırmalar Dergisi, 14(28), 172187. doi:10.30976/susead.302206

Pesaran, B., \& Pesaran, M. H. (2010). Time series econometrics using Microfit 5.0: A user's manual. New York, NY, USA: Oxford University Press, Inc.

Pesaran, M. H., Shin, Y., \& J., S. R. (2001). Bounds testing approaches to the analysis of level relationships. Journal of Applied Econometrics, 16(3), 289-326. doi:10.1002/jae.616 
Phillips, P. C. B., \& Perron, P. (1988). Testing for a unit root in time series regression. Biometrika, 75(2), 335-346. doi:10.1093/biomet/75.2.335

Puni, A., Osei, B. A., \& Barnor, C. (2014). Effects of inflation targeting policy on inflation rates and gross domestic product in Ghana. European Journal of Business and Management, 6(21), 5460. https://iiste.org/Journals/index.php/ EJBM/article/view/14435/14744.

Samimi, A. J., Kenari, S. G., \& Ghajari, M. (2013). The impact of exchange rate on demand for money in Iran. International Journal of Business and Development Studies, 5(1), 39-60. http://ijbds.usb.ac.ir/pdf_1498 -917f3400f9102cd0cfc73305c72fee4d.html.

Sichei, M. M., \& Kamau, A. W. (2012). Demand for money: implications for the conduct of monetary policy in Kenya. International Journal of Economics and Finance, 4(8), 72-82. doi:10.5539/ijef.v4n8p72

Simmons, R. (1992). An error-correction approach to demand for money in five African developing dountries. Journal of Economic Studies, 19(1). doi:10.1108/01443589210015935

The World Bank. (2017). World development indicators (Tech. Rep.). https://databank. worldbank . org/source/world-development-indicators.

Valadkhani, A. (2008). Long- and short-run determinants of the demand for money in the AsianPacific countries: An empirical panel investigation. Annals of Economics and Finance, 9(1), 77-90. http://aeconf.com/Articles/May2008/ aef 090103.pdf.

$\mathrm{Xu}$, L., \& Zia, B. (2012). Financial literacy around the world: an overview of the evidence with practical suggestions for the way forward (Policy Research Working Paper No. 6107). International Monetary Fund http://documents. worldbank. org/curated/en/ $264001468340889422 / p d f / W P S 6107$.pdf. 